\title{
The innate immune response in leprosy
}

\author{
Robert L Modlin 1,2 \\ ${ }^{1}$ Division of Dermatology, Department of Medicine, David Geffen School of Medicine at University \\ of California at Los Angeles (UCLA), CA 90095, USA \\ ${ }^{2}$ Department of Microbiology, Immunology and Molecular Genetics, UCLA, David Geffen School of \\ Medicine at University of California at Los Angeles, 90095, USA
}

\begin{abstract}
Investigation into the innate immune response in leprosy has provided insight into immunoregulation in human infectious disease. Key advances include the role of pattern recognition receptors in recognizing pathogen-associated molecular patterns of Mycobacterium leprae, cytokine release by innate immune cells, macrophage and dendritic cell differentiation, as well as antimicrobial effector pathways. These insights provide targets for therapeutic intervention in modulating the course of leprosy and other chronic infectious diseases.
\end{abstract}

\section{Leprosy as a model}

Leprosy, caused by the intracellular pathogen Mycobacterium leprae, offers an attractive model for investigating the regulation of immune responses to infection. First, the disease itself still poses a significant health and economic burden on developing countries [1]. Although multidrug therapy is reducing the number of active cases to approximately 0.5 million, the number of new cases per year is not declining. Furthermore, patients 'cured' of the infection, have permanent neurologic deficits, can relapse or subsequently undergo tissue-damaging reactions. Second, leprosy is a disease that presents as a spectrum, in which the clinical manifestations correlate with the type of immune response to the pathogen [2], providing an extraordinary opportunity to study resistance versus susceptibility to a microbial pathogen.

At one end of the disease spectrum, patients with tuberculoid leprosy (T-lep) typify the resistant response that restricts the growth of the pathogen. The number of lesions is few and bacilli rare, although tissue and nerve damage are frequent. At the opposite end of this spectrum, patients with lepromatous leprosy (L-lep) represent susceptibility to disseminated infection. Skin lesions are numerous and growth of the pathogen is unabated. These clinical presentations correlate with the level of cell-mediated immunity (CMI) against $M$. leprae. The standard measure of CMI to the pathogen is the Mitsuda reaction or lepromin skin test, a three-week response to intradermal challenge with $M$. leprae. The test is positive in T-lep patients but negative in lepromatous patients. Interestingly, antibody responses are greater in L-lep patients, indicating that humoral immunity does not contribute to host defense.

The inverse correlation between CMI and humoral immunity was initially investigated in terms of the adaptive immune response. Distinct T cell subsets correlate with the response to $M$. leprae including CD4 and CD8 T cells [3] and the T cell cytokine patterns they produce [46]. $\mathrm{CD} 4+\mathrm{T}$ cells that produce the type 1 or Th 1 cytokine pattern including IFN- $\gamma$ predominate in T-lep lesions; whereas, CD8+ T cells that produce the type 2 or Th2 cytokine pattern

(C) 2009 Elsevier Ltd. All rights reserved.

Corresponding author: Modlin, Robert L (rmodlin@mednet.ucla.edu). 
including IL-4 predominate in L-lep lesions. The nature of the adaptive T cell response is determined in part by the instruction of the innate immune response. Therefore, leprosy provides an excellent model to investigate mechanisms by which the innate immune system determines outcome in human infectious disease.

\section{Recognition of $\boldsymbol{M}$. leprae by the innate immune system}

In 1884, Metchnikoff described the key features of the modern innate immune system. Cells that mediated the innate response, which he termed 'phagocytes', were able to rapidly recognize, phagocytose, and destroy the foreign invader [7••]. Over 100 hundred years later, we have gained considerable insight into some of the mechanisms by which the innate immune system recognizes microbial invaders. Cells of the innate immune system are equipped with germ line encoded pattern recognition receptors (PRRs), which recognize pathogen-associated molecular patterns (PAMPs), which are shared among groups of pathogens.

\section{Toll-like receptor 2/1 (TLR2/1)}

From the study of M. tuberculosis and related species, we have gained insight into the receptors that mediate the response to mycobacteria. Several Toll-like receptors (TLRs) clearly mediate innate immune recognition of M. tuberculosis and related species. Experiments performed in the Modlin lab [8] and other labs [9] led to the exciting finding that microbial lipoproteins trigger host responses via TLR2, requiring the acyl functions for activity. Subsequently, triacylated lipoproteins were found to activate TLR2/1 heterodimers [10], whereas diacylated lipoproteins were found to activate TLR2/6 heterodimers. TLR2 also mediates the response to the lipoarabinomannan from rapidly growing mycobacteria [11], and in combination with MARCO and CD14 to mycobacterial trehalose dimycolate [12••]. TLR2 has been shown to be important for resistance to TB in mouse models of infection [13-15].

The expression and activation of TLRs was investigated in leprosy [16]. TLR2-TLR1 heterodimers mediated cell activation by killing $M$. leprae, indicating the presence of triacylated lipoproteins. A genome-wide scan of $M$. leprae detected 31 putative lipoproteins. Synthetic lipopeptides representing the 19-kDa and 33-kDa lipoproteins activated both monocytes and dendritic cells (DCs). Additional studies demonstrated that the M. leprae 33$\mathrm{kDa}$ lipoprotein [17] and the M. leprae major membrane protein-II (MMP-II) [18], also a lipoprotein, triggered TLR2 responses, requiring the acyl functions and the polypeptide region for optimal activity. Activation was enhanced by type 1 cytokines and inhibited by type 2 cytokines. In addition, the type 1 cytokines, IFN- $\gamma$ and GM-CSF, enhanced TLR1 expression in monocytes and DCs, respectively, whereas the type 2 cytokine, IL-4 downregulated TLR2 expression. TLR2 and TLR1 were more strongly expressed in lesions from the localized T-lep form as compared with the disseminated L-lep form of the disease.

Ultimately, the activation of the TLR2/1 heterodimer by $M$. leprae lipopeptides triggered the production of cytokines such as TNF- $\alpha$, as part of the acute inflammatory response [16] and IL-12, which mediates the instructive role of the innate immune response in instructing the adaptive type 1 or Th 1 cytokine response [16]. Activation of TLR2/1 also upregulated receptorligand pairs as part of an autocrine response including GM-CSF and its receptor leading to the expansion of DC and IL-15 and its receptor components leading to $M \Phi$ differentiation [19]. Together, these data provided evidence that regulated expression and activation of TLRs at the site of disease contribute to the host defense against microbial pathogens.

A number of mechanisms have been identified, which regulate TLR function in leprosy. In addition to the ability of IL-4 to downregulate TLR2/1 expression, it also inhibits TLR2/1induced cytokine responses [16]. IL-10 had no effect on TLR $2 / 1$ expression but strongly inhibit TLR2/1-induced cytokine release [16]. Activation of LILRA2, which is differentially 
expressed in L-lep versus T-lep lesions, inhibited TLR2/1-induced IL-12 release but preserved IL-10 release [20]. Similarly, oxidized phospholipids inhibited TLR2/1-induced IL-12 release but preserved IL-10 release [21•]. The ability of $M$. leprae to upregulate tryptophan aspartatecontaining coat protein (TACO), known to be expressed in macrophages containing M. leprae in vitro and in disease lesions [22], was shown to downregulate TLR2-mediated signaling $[23 \bullet \bullet$.

\section{TLR2 and TLR1 SNPs}

Polymorphisms in TLR2 and TLR1 genes have been investigated in patients with leprosy. Initially, a TLR2 SNP was found to be associated with susceptibility in leprosy [24], prompting functional investigations using transfections of the altered TLR2 gene [25-28]. This SNP has been recently identified in a pseudogene and does not encode a TLR 2 transcripts [29]. However, there is compelling data to suggest that polymorphisms in the TLR1 gene may contribute to the TLR2/1 response to lipopeptides, and to the pathogenesis of leprosy. The TLR1 T1805G SNP (I602S), rs5743618 affects TLR1 surface expression and subsequent activation by mycobacterial lipopeptides $[30 \bullet \bullet, 31 \bullet \bullet]$. The TLR1 I602S SNP was associated with a decreased incidence of leprosy [30••] and protection against reversal reaction [31 ••]. The TLR1 A743G SNP (N248S) rs5433095 is in linkage disequilibrium with TLR1 1805, but had little effect on function in transfection studies when separated from the TLR1 1805 allele [32]. TLR1 248SS is associated with protection against leprosy [33]. It would seem puzzling that a polymorphism that would reduce TLR2/1 signaling would protect against leprosy and reversal reaction. However, Johnson et al. reason that the TLR response may be critical during the acute infection, but a moderation of the innate response may be beneficial in chronic infectious diseases such as leprosy [ $30^{\bullet} \cdot$. Consistent with this hypothesis is the finding that TLR2/1 activation can lead to tissue injury, including nerve damage in leprosy [34].

\section{Other TLRs and PRRs}

TLR4 has been reported to be required for the host defense against M. tuberculosis [35], and shown to mediate the response to mycobacterial heat shock proteins [36], although these studies are frequently criticized because the recombinant proteins used may contain amounts of endotoxin sufficient to activate TLR4 [37,38]. Two TLR4 SNPs, TLR4 D299G and T399I were found to be associated with a protective effect against leprosy [39••]. Finally, TLR 9 has a role in recognition of bacterial CpG DNA, participating in the response to mycobacteria [15]. A polymorphism in TIRAP, a signaling molecule downstream of the TLRs, TIRAP S180L has been associated with protection against leprosy infection [40].

A comprehensive study of TLR pathway gene polymorphisms in mycobacterial infection analyzed 149 SNPs in 18 genes involved in the TLR pathway in susceptibility to TB [41••]. Although SNPs in the TLR9 and TOLLIP genes were found to be associated with TB, the allele frequencies were low. However, four polymorphisms, all in the TLR8 gene showed statistical evidence of association with resistance to TB (odds ratio 1.2-1.8) and were prevalent (ranging from 25 to $75 \%$ ) in various populations. These results warrant studying whether TLR8 polymorphisms play a role in protection against leprosy infection.

Nucleotide-binding oligomerization domain 2 (NOD2) is a cytoplasmic receptor belonging to the NOD-like receptor family. It not only shares homology to TLRs in containing leucine rich repeats but also encodes a CARD domain. It mediates the response to peptidoglycan, including that derived from mycobacteria, by sensing muramyl dipeptide (MDP) $[42,43]$. Triggering of NOD2 by MDP activates NF- $\kappa$ B through the adaptor molecule, RIP2. In addition, MDP can also activate the inflammasome, by recruitment of caspase-1, leading to the proteolytic cleavage and activation of IL-1 $\beta$ [44]. NOD2 deficiency in a mouse model of TB resulted in increased susceptibility to infection at late timepoints $[45,46]$. NOD2 polymorphisms, not those 
associated with Crohn's disease, were shown to be associated with susceptibility to TB [47]. NOD2 was not only found to mediate the response tom TB in human monocytes and synergize with lipoprotein in activating monocyte cytokine responses [48], but also synergized with transfected DNA in activating the IFN- $\beta$ pathway [49].

\section{Vitamin $D$ and innate immunity}

The ability of TLRs to trigger a direct antimicrobial activity is a major aspect of their role in innate immunity. In mouse monocytes, TLR2-induced antimicrobial activity is NO dependent, but in human monocytes is NO independent [50]. Instead, a key antimicrobial mechanism for TLR-activated human monocytes involves induction of the 25-hydroxyvitamin D3-1 $\alpha-$ hydroxylase (CYP27b1), which converts the 25D into the active 1,25D form, upregulation and activation of the vitamin D receptor (VDR) and downstream induction of the antimicrobial peptide cathelicidin [51,52 •,53-55]. The ability of TLR2/1 activation to upregulate expression of CYP27b1 and the VDR is IL-15 dependent [19]. Simultaneous triggering of IL-1 $\beta$ activity and activation of the VDR induces DEFB4, also required for antimicrobial activity [56•]. The TLR-induction of antimicrobial peptides have been preserved during evolution; activation of drosophila Toll, which has been shown to trigger induction of several antimicrobial peptides [57]. An important aspect of this study was the discovery that induction of cathelicidin required the use of 25D-sufficient human serum and was not observed with 25D-insufficient human serum or fetal calf serum (which is also 25D-insufficient).

There is evidence to suggest that the vitamin $\mathrm{D}$ antimicrobial pathway may contribute to disease outcome in leprosy. Several studies suggest that polymorphisms in the VDR are associated with the type of disease, specifically the Taq I polymorphism [58-60]. Analysis of gene expression profiles in leprosy lesions indicated that genes encoding for key components of the vitamin D antimicrobial pathway were differentially expressed in T-lep versus L-lep lesions [61•]. The induction of antimicrobial peptides is thought to be relevant to host defense in leprosy, given the finding that a polymorphism in the NF- $\mathrm{\kappa B} 1$ putative binding site of DEFB1 (human $\beta$-defensin 1), DEFB1 G668C is associated with L-lep disease [62].

\section{Macrophages in L-lep lesions accumulated host-derived oxidized lipid}

In Metchnikoff's model of innate immunity, recognition of the microbial pathogen was followed by phagocytosis. A key cell of the mammalian innate immune system that mediates phagocytosis of microbial pathogens is the macrophage (MФ). By conventional histology, the $\mathrm{M} \Phi$ in the different forms of leprosy are distinct. In T-lep lesions, the $\mathrm{M} \Phi$ is thought to be activated, resembling epithelial cells, and are hence called epithelioid cells. In L-lep lesions, the $M \Phi$ besides containing numerous bacilli have a characteristic foamy appearance, first described by Rudolf Virchow in 1863. 'In the fresh state they have one characteristic that is especially noteworthy, i.e., their tendency to form a sort of vacuole, apparently from taking up water, so that under the circumstances they acquire a wholly physaliferous appearance' [63]. It has generally been thought that such cells, termed Virchow cells, lepra cells or foam cells are МФ containing large amounts of lipids including phospholipids and fatty acids, presumed to be of mycobacterial origin [64].

By probing the profiles of differentially expressed genes in T-lep and L-lep lesions [20], we found a marked upregulation of host lipid metabolism genes in the L-lep versus T-lep lesions [21•]. Moreover, the lipid within foam cells in L-lep lesions contains host-derived oxidized phospholipids. In vitro, we found that mycobacteria induce in МФ the intracellular accumulation of a specific host-derived oxidized phospholipid, 1-palmitoyl-2-(5,6epoxyisoprostane E2)-sn-glycero-3-phosphorylcholine (PEIPC) providing a mechanistic link to the foam cells found in atherosclerosis lesions. In atherosclerosis, foam cells are derived from monocytes that enter the subendothelial space, differentiate into $M \Phi$, and endocytose 
modified forms of LDL [65]. They are defined by the intracellular presence of distinct components of oxLDL: oxidized phospholipids, esterified cholesterol, and apolipoprotein B (ApoB); the latter is also expressed in L-lep lesions [66]. Foamy, lipid-laden $M \Phi$ are a frequent pathological observation in tuberculosis [67-72], with mycobacterial components such as mycoli acid able to promote $\mathrm{M} \Phi$ accumulation of cholesterol ester and lipid body formation [73-76]. The ability of mycobacteria to promote lipid body formation appears to be dependent on TLR2 signaling [76] and PPAR- $\gamma$ activation [77]. Furthermore, the accumulation of lipids in phagosomes in L-lep lesions involves lipid-droplet associated proteins adipose differentiation-related protein (ADRP) and perilipin [78••].

Presumably, the accumulation of host-derived lipids favor mycobacterial growth, which in vivo depends on the use of fatty acids by the glyoxylate shunt [21•]. The metabolism of host fatty acids to methyl malonyl CoA is coupled with M. tuberculosis pathogenesis through its incorporation into lipid-containing virulence factors [21•]. In addition, mycobacterial infection and host-derived oxidized phospholipids both inhibited innate immune responses, and this inhibition was reversed by the addition of normal HDL, a scavenger of oxidized phospholipids, but not by HDL from L-lep patients. These data point to striking similarities in the pathogenesis of foam cell formation in mycobacterial infection to atherosclerosis, implying a common metabolic and inflammatory process.

\section{Divergence of macrophage phagocytic and antimicrobial programs in leprosy}

In addition to their phagocytic function, $\mathrm{M} \Phi$ also mediate an antimicrobial activity against infectious agents. The mechanisms that regulate these $\mathrm{M} \Phi$ antimicrobial and phagocytic functions are central to our understanding of innate immune responses against microbial pathogens. Despite the histologic differences of MФ infiltrating T-lep versus L-lep lesions, the frequency of CD209 expressing MФ is similar in the lesions of all forms of the disease [19].

CD209 is a C-type lectin that contains carbohydraterecognition domains (CRD) enabling cytokine-derived DCs to recognize pathogens containing mannose-rich glycoconjugates, including the mycobacterial lipoglycan mannosylated lipoarabinomannan (ManLAM) [79]. This recognition allows CD209 to mediate binding and phagocytosis of a broad range of pathogens, including, M. leprae [80] and is expressed in both the T-lep and L-lep forms of leprosy [19].

Although MФ in both T-lep and L-lep lesions expressed CD209 [19], we reasoned that different $\mathrm{M} \Phi$ functional programs contributed to the pathogenesis of leprosy. Clearly, the distinct $\mathrm{T}$ cell cytokine patterns in leprosy lesions can influence $M \Phi$ function [5,81]; however, we thought it was likely that the cytokine of the innate immune response had direct effects on $M \Phi$ function. Of the innate immune cytokines known to regulate $\mathrm{M} \Phi$ function, T-lep lesions express IL-15 [5,81], whereas, L-lep lesions are characterized by the expression of IL-10 [5,81], prompting the comparison of the IL-15 and IL-10 induced MФ differentiation [61 •]. Both IL-10 and IL-15 upregulated CD209 expression on monocytes, however they induced M $\Phi$ functional programs. IL-10 induced the phagocytic pathway, including a scavenger receptor program, resulting in the phagocytosis of mycobacteria and oxLDL. In contrast, IL-15 induced the vitamin Ddependent antimicrobial pathway, yet the cells were less phagocytic. The differential regulation of macrophage functional programs was confirmed by analysis of the spectrum of leprosy lesions: the macrophage phagocytosis pathway was prominent in the clinically progressive Llep form, whereas the vitamin D-dependent antimicrobial pathway predominated in the selflimited T-lep form of the disease and in patients undergoing reversal reactions from the multibacillary to the self-limited form. Polymorphisms in the IL-10 locus have been investigated by several groups with conflicting results $[60,82,83 \bullet \bullet, 84-86]$. Paradoxically, one IL-10 promoter 
polymorphism, $819 \mathrm{C} / \mathrm{T}$, was associated with susceptibility to leprosy, and could lead to decreased IL-10 production $[82,83 \bullet \bullet, 84]$. In summary, these data indicate that macrophage programs for phagocytosis and antimicrobial responses are distinct and differentially regulated in innate immunity in bacterial infections.

\section{Dendritic cell deficit in lepromatous leprosy}

The ability of the innate immune system to instruct the adaptive $\mathrm{T}$ cell response is part of an effective host defense against intracellular pathogens. This instructive role of the innate immune system is primarily mediated by DCs, professional antigen-presenting cells [87] that are highly efficient in activation of $\mathrm{T}$ cell responses that provide $\mathrm{CMI}$ against the pathogen [88]. L-lep lesions are characterized by a marked deficit in DCs, both in the dermis and epidermis [89-91], a potential mechanism for the reduced cell-mediated immune responses in these lesions [2]. DCs differentiate from myeloid precursors, a process that can be interrupted by inhibitory receptors as well as host-derived oxidized phospholipids that are found in L-lep lesions [20,92]. In addition, peripheral monocytes from L-lep patients do not differentiate into CD1+ DC following TLR activation [19]. Expression of the costimulatory protein, B7.1, is also decreased in L-lep lesions [93], further suggesting impaired CMI. The activation and maturation of DCs can be directly inhibited by the pathogen itself, in contrast to other mycobacteria [94••], suggesting that the pathogen specifically subverts the generation of functional antigen-presenting cells. Together these studies suggest that $M$. leprae contributes to reduced cell-mediated immune responses in leprosy by disrupting the differentiation of DCs and their antigen-presenting capacity.

In conclusion, leprosy has provided an exciting model to investigate the key role of the human innate immune system in host defense against versus susceptibility to microbial infection. It is hoped that these insights will lead to new therapeutic interventions for leprosy and other infectious diseases worldwide.

\section{Acknowledgments}

I am grateful to Stephan Krutzik, Peter Sieling, Dennis Montoya, and Mario Fabri for their helpful discussions. This work was supported by the following NIH grants: AI022553, AR040312, AI073539, and AI047868.

\section{References and recommended reading}

Papers of particular interest, published within the period of review, have been highlighted as:

- of special interest

•• of outstanding interest

1. Bloom BR. Learning from leprosy: a perspective on immunology and the third world. J Immunol 1986;137:i-i10. [PubMed: 2423599]

2. Ridley DS, Jopling WH. Classification of leprosy according to immunity. A five-group system. Int J Lepr 1966;34:255-273.

3. Modlin RL, Hofman FM, Taylor CR, Rea TH. T lymphocyte subsets in the skin lesions of patients with leprosy. J Am Acad Dermatol 1983;8:182-189. [PubMed: 6219136]

4. Cooper CL, Mueller C, Sinchaisri T-A, Pirmez C, Chan J, Kaplan G, Young SMM, Weissman IL, Bloom BR, Rea TH, Modlin RL. Analysis of naturally occurring delayed-type hypersensitivity reactions in leprosy by in situ hybridization. J Exp Med 1989;169:1565-1581. [PubMed: 2523952]

5. Yamamura M, Uyemura K, Deans RJ, Weinberg K, Rea TH, Bloom BR, Modlin RL. Defining protective responses to pathogens: cytokine profiles in leprosy lesions. Science 1991;254:277-279. [PubMed: 1925582] 
6. Yamamura M, Wang X-H, Ohmen JD, Uyemura K, Rea TH, Bloom BR, Modlin RL. Cytokine patterns of immunologically mediated tissue damage. J Immunol 1992;149:1470-1475. [PubMed: 1500726]

7. Metschnikoff E. Ueber eine Sprosspilzkrankheit der Daphnien. Beitrag zur Lehre uber den Kampf der Phagocyten gegen Krankheitserrenger. Archiv f.pathologische Anatomie und Physiologie und f.klinische Medicin 1884;96:177-195.. The most classic work.

8. Brightbill HD, Libraty DH, Krutzik SR, Yang RB, Belisle JT, Bleharski JR, Maitland M, Norgard MV, Plevy SE, Smale ST, et al. Host defense mechanisms triggered by microbial lipoproteins through tolllike receptors. Science 1999;285:732-736. [PubMed: 10426995]

9. Aliprantis AO, Yang R-B, Mark MR, Suggett S, Devaux B, Radolf JD, Klimpel GR, Godowski P, Zychlinsky A. Cell activation and apoptosis by bacterial lipoproteins through Toll-like receptor-2. Science 1999;285:736-739. [PubMed: 10426996]

10. Takeuchi O, Sato S, Horiuchi T, Hoshino K, Takeda K, Dong Z, Modlin RL, Akira S. Cutting edge: role of Toll-like receptor 1 in mediating immune response to microbial lipoproteins. J Immunol 2002;169:10-14. [PubMed: 12077222]

11. Means TK, Wang S, Lien E, Yoshimura A, Golenbock DT, Fenton MJ. Human Toll-Like receptors mediate cellular activation by Mycobacterium tuberculosis. J Immunol 1999;163:3920-3927. [PubMed: 10490993]

12. Bowdish DM, Sakamoto K, Kim MJ, Kroos M, Mukhopadhyay S, Leifer CA, Tryggvason K, Gordon S, Russell DG. MARCO, TLR2, and CD14 are required for macrophage cytokine responses to mycobacterial trehalose dimycolate and Mycobacterium tuberculosis. PLoS Pathog 2009;5:e1000474. [PubMed: 19521507]. An elegant study showing a novel mechanism by which a pathogen-associated molecular pattern is recognized by a pattern recognition receptor.

13. Reiling N, Holscher C, Fehrenbach A, Kroger S, Kirschning CJ, Goyert S, Ehlers S. Cutting edge: Toll-like receptor (TLR)2- and TLR4-mediated pathogen recognition in resistance to airborne infection with Mycobacterium tuberculosis. J Immunol 2002;169:3480-3484. [PubMed: 12244136]

14. Drennan MB, Nicolle D, Quesniaux VJ, Jacobs M, Allie N, Mpagi J, Fremond C, Wagner H, Kirschning C, Ryffel B. Toll-like receptor 2-deficient mice succumb to Mycobacterium tuberculosis infection. Am J Pathol 2004;164:49-57. [PubMed: 14695318]

15. Bafica A, Scanga CA, Feng CG, Leifer C, Cheever A, Sher A. TLR9 regulates Th1 responses and cooperates with TLR2 in mediating optimal resistance to Mycobacterium tuberculosis. J Exp Med 2005;202:1715-1724. [PubMed: 16365150]

16. Krutzik SR, Ochoa MT, Sieling PA, Uematsu S, Ng YW, Legaspi A, Liu PT, Cole ST, Godowski PJ, Maeda Y, et al. Activation and regulation of Toll-like receptors 2 and 1 in human leprosy. Nat Med 2003;9:525-532. [PubMed: 12692544]

17. Yamashita Y, Maeda Y, Takeshita F, Brennan PJ, Makino M. Role of the polypeptide region of a 33 kDa mycobacterial lipoprotein for efficient IL-12 production. Cell Immunol 2004;229:13-20. [PubMed: 15331324]

18. Maeda Y, Mukai T, Spencer J, Makino M. Identification of an immunomodulating agent from Mycobacterium leprae. Infect Immun 2005;73:2744-2750. [PubMed: 15845477]

19. Krutzik SR, Tan B, Li H, Ochoa MT, Liu PT, Sharfstein SE, Graeber TG, Sieling PA, Liu YJ, Rea $\mathrm{TH}$, et al. TLR activation triggers the rapid differentiation of monocytes into macrophages and dendritic cells. Nat Med 2005;11:653-660. [PubMed: 15880118]

20. Bleharski JR, Li H, Meinken C, Graeber TG, Ochoa MT, Yamamura M, Burdick A, Sarno EN, Wagner $\mathrm{M}$, Rollinghoff $\mathrm{M}$, et al. Use of genetic profiling in leprosy to discriminate clinical forms of the disease. Science 2003;301:1527-1530. [PubMed: 12970564]

21. Cruz D, Watson AD, Miller CS, Montoya D, Ochoa MT, Sieling PA, Gutierrez MA, Navab M, Reddy ST, Witztum JL, et al. Host-derived oxidized phospholipids and HDL regulate innate immunity in human leprosy. J Clin Invest 2008;118:2917-2928. [PubMed: 18636118] . This study provides new information on foam cells in leprosy.

22. Suzuki K, Takeshita F, Nakata N, Ishii N, Makino M. Localization of CORO1A in the macrophages containing Mycobacterium leprae. Acta Histochem Cytochem 2006;39:107-112. [PubMed: 17327897]

23. Tanigawa K, Suzuki K, Kimura H, Takeshita F, Wu H, Akama T, Kawashima A, Ishii N. Tryptophan aspartate-containing coat protein (CORO1A) suppresses Toll-like receptor signalling in 
Mycobacterium leprae infection. Clin Exp Immunol 2009;156:495-501. [PubMed: 19438603] . A key study on the phagolysosome and its effect on TLR signaling.

24. Kang TJ, Chae GT. Detection of Toll-like receptor 2 (TLR2) mutation in the lepromatous leprosy patients. FEMS Immunol Med Microbiol 2001;31:53-58. [PubMed: 11476982]

25. Kang TJ, Lee SB, Chae GT. A polymorphism in the toll-like receptor 2 is associated with IL-12 production from monocyte in lepromatous leprosy. Cytokine 2002;20:56-62. [PubMed: 12445799]

26. Bochud PY, Hawn TR, Aderem A. Cutting edge: a Toll-like receptor 2 polymorphism that is associated with lepromatous leprosy is unable to mediate mycobacterial signaling. J Immunol 2003;170:3451-3454. [PubMed: 12646604]

27. Schroder NW, Hermann C, Hamann L, Gobel UB, Hartung T, Schumann RR. High frequency of polymorphism Arg753Gln of the Toll-like receptor-2 gene detected by a novel allelespecific PCR. J Mol Med 2003;81:368-372. [PubMed: 12743710]

28. Kang TJ, Yeum CE, Kim BC, You EY, Chae GT. Differential production of interleukin-10 and interleukin-12 in mononuclear cells from leprosy patients with a Toll-like receptor 2 mutation. Immunology 2004;112:674-680. [PubMed: 15270740]

29. Malhotra D, Relhan V, Reddy BS, Bamezai R. TLR2 Arg677Trp polymorphism in leprosy: revisited. Hum Genet 2005;116:413-415. [PubMed: 15726416]

30. Johnson CM, Lyle EA, Omueti KO, Stepensky VA, Yegin O, Alpsoy E, Hamann L, Schumann RR, Tapping RI. Cutting edge: a common polymorphism impairs cell surface trafficking and functional responses of TLR1 but protects against leprosy. J Immunol 2007;178:7520-7524. [PubMed: 17548585] . A key study on the role of a TLR1 SNP in leprosy.

31. Misch EA, Macdonald M, Ranjit C, Sapkota BR, Wells RD, Siddiqui MR, Kaplan G, Hawn TR. Human TLR1 deficiency is associated with impaired mycobacterial signaling and protection from leprosy reversal reaction. PLoS Negl Trop Dis 2008;2:e231. [PubMed: 18461142] . An outstanding genetic study on a TLR1 polymorphism in leprosy.

32. Omueti KO, Mazur DJ, Thompson KS, Lyle EA, Tapping RI. The polymorphism P315L of human toll-like receptor 1 impairs innate immune sensing of microbial cell wall components. J Immunol 2007;178:6387-6394. [PubMed: 17475868]

33. Schuring RP, Hamann L, Faber WR, Pahan D, Richardus JH, Schumann RR, Oskam L. Polymorphism $\mathrm{N} 248 \mathrm{~S}$ in the human Toll-like receptor 1 gene is related to leprosy and leprosy reactions. J Infect Dis 2009;199:1816-1819. [PubMed: 19456232]

34. Oliveira RB, Ochoa MT, Sieling PA, Rea TH, Rambukkana A, Sarno EN, Modlin RL. Expression of Toll-like receptor 2 on human Schwann cells: a mechanism of nerve damage in leprosy. Infect Immun 2003;71:1427-1433. [PubMed: 12595460]

35. Means TK, Wang S, Lien E, Yoshimura A, Golenbock DT, Fenton MJ. Human toll-like receptors mediate cellular activation by Mycobacterium tuberculosis. J Immunol 1999;163:3920-3927. [PubMed: 10490993]

36. Bulut Y, Michelsen KS, Hayrapetian L, Naiki Y, Spallek R, Singh M, Arditi M. Mycobacterium tuberculosis heat shock proteins use diverse Toll-like receptor pathways to activate pro-inflammatory signals. J Biol Chem 2005;280:20961-20967. [PubMed: 15809303]

37. Gao B, Tsan MF. Endotoxin contamination in recombinant human heat shock protein 70 (Hsp70) preparation is responsible for the induction of tumor necrosis factor alpha release by murine macrophages. J Biol Chem 2003;278:174-179. [PubMed: 12403778]

38. Marincek BC, Kuhnle MC, Srokowski C, Schild H, Hammerling G, Momburg F. Heat shock proteinantigen fusions lose their enhanced immunostimulatory capacity after endotoxin depletion. Mol Immunol 2008;46:181-191. [PubMed: 18804283]

39. Bochud PY, Sinsimer D, Aderem A, Siddiqui MR, Saunderson P, Britton S, Abraham I, Tadesse AA, Janer M, Hawn TR, Kaplan G. Polymorphisms in Toll-like receptor 4 (TLR4) are associated with protection against leprosy. Eur J Clin Microbiol Infect Dis 2009;28:1055-1065. [PubMed: 19430824] . The key study on TLR4 polymorphisms in leprosy.

40. Hamann L, Kumpf O, Schuring RP, Alpsoy E, Bedu-Addo G, Bienzle U, Oskam L, Mockenhaupt FP, Schumann RR. Low frequency of the TIRAP S180L polymorphism in Africa, and its potential role in malaria, sepsis, and leprosy. BMC Med Genet 2009;10:65. [PubMed: 19602285] 
41. Davila S, Hibberd ML, Hari DR, Wong HE, Sahiratmadja E, Bonnard C, Alisjahbana B, Szeszko JS, Balabanova Y, Drobniewski F, et al. Genetic association and expression studies indicate a role of toll-like receptor 8 in pulmonary tuberculosis. PLoS Genet 2008;4:e1000218. [PubMed: 18927625] . A thorough analysis of TLR polymorphisms in tuberculosis.

42. Yang Y, Yin C, Pandey A, Abbott D, Sassetti C, Kelliher MA. NOD2 pathway activation by MDP or Mycobacterium tuberculosis infection involves the stable polyubiquitination of Rip2. J Biol Chem 2007;282:36223-36229. [PubMed: 17947236]

43. Girardin SE, Boneca IG, Viala J, Chamaillard M, Labigne A, Thomas G, Philpott DJ, Sansonetti PJ. Nod2 is a general sensor of peptidoglycan through muramyl dipeptide (MDP) detection. J Biol Chem 2003;278:8869-8872. [PubMed: 12527755]

44. Delbridge LM, O’Riordan MX. Innate recognition of intracellular bacteria. Curr Opin Immunol 2007;19:10-16. [PubMed: 17126540]

45. Gandotra S, Jang S, Murray PJ, Salgame P, Ehrt S. Nucleotide-binding oligomerization domain protein 2-deficient mice control infection with Mycobacterium tuberculosis. Infect Immun 2007;75:5127-5134. [PubMed: 17709422]

46. Divangahi M, Mostowy S, Coulombe F, Kozak R, Guillot L, Veyrier F, Kobayashi KS, Flavell RA, Gros P, Behr MA. NOD2-deficient mice have impaired resistance to Mycobacterium tuberculosis infection through defective innate and adaptive immunity. J Immunol 2008;181:7157-7165. [PubMed: 18981137]

47. Austin CM, Ma X, Graviss EA. Common nonsynonymous polymorphisms in the NOD2 gene are associated with resistance or susceptibility to tuberculosis disease in African Americans. J Infect Dis 2008;197:1713-1716. [PubMed: 18419343]

48. Ferwerda G, Girardin SE, Kullberg BJ, Le BL, de Jong DJ, Langenberg DM, van CR, Adema GJ, Ottenhoff TH, Van der Meer JW, Netea MG. NOD2 and toll-like receptors are nonredundant recognition systems of Mycobacterium tuberculosis. PLoS Pathog 2005;1:279-285. [PubMed: 16322770]

49. Leber JH, Crimmins GT, Raghavan S, Meyer-Morse NP, Cox JS, Portnoy DA. Distinct TLR- and NLR-mediated transcriptional responses to an intracellular pathogen. PLoS Pathog 2008;4:e6. [PubMed: 18193943]

50. Thoma-Uszynski S, Stenger S, Takeuchi O, Ochoa MT, Engele M, Sieling PA, Barnes PF, Rollinghoff M, Bolcskei PL, Wagner M, et al. Induction of direct antimicrobial activity through mammalian tolllike receptors. Science 2001;291:1544-1547. [PubMed: 11222859]

51. Wang TT, Nestel FP, Bourdeau V, Nagai Y, Wang Q, Liao J, Tavera-Mendoza L, Lin R, Hanrahan JW, Mader S, White JH. Cutting edge: 1,25-dihydroxyvitamin D3 is a direct inducer of antimicrobial peptide gene expression. J Immunol 2004;173:2909-2912. [PubMed: 15322146]

52. Martineau AR, Wilkinson KA, Newton SM, Floto RA, Norman AW, Skolimowska K, Davidson RN, Sorensen OE, Kampmann B, Griffiths CJ, Wilkinson RJ. IFN-\{gamma\}-, TNF-independent vitamin D-inducible human suppression of Mycobacteria: the role of cathelicidin LL-37. J Immunol 2007;178:7190-7198. [PubMed: 17513768] . A key study on the role of cathelicidin in mycobacterial infection.

53. Liu PT, Stenger S, Tang DH, Modlin RL. Cutting edge: vitamin D-mediated human antimicrobial activity against Mycobacterium tuberculosis is dependent on the induction of cathelicidin. J Immunol 2007;179:2060-2063. [PubMed: 17675463]

54. Liu PT, Stenger S, Li H, Wenzel L, Tan BH, Krutzik SR, Ochoa MT, Schauber J, Wu K, Meinken $\mathrm{C}$, et al. Toll-like receptor triggering of a vitamin D-mediated human antimicrobial response. Science 2006;311:1770-1773. [PubMed: 16497887]

55. Krutzik SR, Hewison M, Liu PT, Robles JA, Stenger S, Adams JS, Modlin RL. IL-15 links TLR2/1induced macrophage differentiation to the vitamin D-dependent antimicrobial pathway. J Immunol 2008;181:7115-7120. [PubMed: 18981132]

56. Liu PT, Schenk M, Walker VP, Dempsey PW, Kanchanapoomi M, Wheelwright M, Vazirnia A, Zhang X, Steinmeyer A, Zugel U, et al. Convergence of IL-1beta and VDR activation pathways in human TLR2/1-induced antimicrobial responses. PLoS ONE 2009;4:e5810. [PubMed: 19503839] . This study shows that multiple antimicrobial peptides are required for host defense against mycobacterial infection. 
57. Lemaitre B, Nicolas E, Michaut L, Reichhart JM, Hoffmann JA. The dorsoventral regulatory gene cassette spatzle/Toll/cactus controls the potent antifungal response in Drosophila adults. Cell 1996;86:973-983. [PubMed: 8808632]

58. Roy S, Frodsham A, Saha B, Hazra SK, Mascie-Taylor CG, Hill AV. Association of vitamin D receptor genotype with leprosy type. J Infect Dis 1999;179:187-191. [PubMed: 9841838]

59. Goulart LR, Ferreira FR, Goulart IM. Interaction of TaqI polymorphism at exon 9 of the vitamin D receptor gene with the negative lepromin response may favor the occurrence of leprosy. FEMS Immunol Med Microbiol 2006;48:91-98. [PubMed: 16965356]

60. Fitness J, Floyd S, Warndorff DK, Sichali L, Mwaungulu L, Crampin AC, Fine PE, Hill AV. Largescale candidate gene study of leprosy susceptibility in the Karonga district of northern Malawi. Am J Trop Med Hyg 2004;71:330-340. [PubMed: 15381816]

61. Montoya D, Cruz D, Teles RM, Lee DJ, Ochoa MT, Krutzik SR, Chun R, Schenk M, Zhang X, Ferguson BG, et al. Divergence of macrophage phagocytic and antimicrobial programs in leprosy. Cell Host Microbe 2009;6:343-353. [PubMed: 19837374] . This study correlates in vitro function of macrophages with phenotype in leprosy lesions.

62. Prado-Montes, de OE.; Velarde-Felix, JS.; Rios-Tostado, JJ.; Picos-Cardenas, VJ.; Figuera, LE. SNP 668C (-44) alters a NF-kappaB1 putative binding site in non-coding strand of human beta-defensin 1 (DEFB1) and is associated with lepromatous leprosy. Infect Genet Evol 2009;9:617-625. [PubMed: 19460328]

63. Virchow, R. Die krankhaften Geschwülste. Berlin: August Hirschwald; 1863.

64. Sakurai I, Skinsnes OK. Lipids in leprosy. 2. Histochemistry of lipids in human leprosy. Int J Lepr Other Mycobact Dis 1970;38:389-403. [PubMed: 4102020]

65. Navab M, Ananthramaiah GM, Reddy ST, Van Lenten BJ, Ansell BJ, Fonarow GC, Vahabzadeh K, Hama S, Hough G, Kamranpour N, et al. The oxidation hypothesis of atherogenesis: the role of oxidized phospholipids and HDL. J Lipid Res 2004;45:993-1007. [PubMed: 15060092]

66. Ridley MJ, Ridley DS, De Beer FC, Pepys MB. C-reactive protein and apoB containing lipoproteins are associated with Mycobacterium leprae in lesions of human leprosy. Clin Exp Immunol 1984;56:545-552. [PubMed: 6378453]

67. Gunn, FD. Tuberculosis. In: Anderson, WAD., editor. Pathology. edn 4.. St. Louis: C.V. Mosby Company; 1961. p. 243-263.

68. Osler, W. Tuberculosis. In: Osler, W., editor. The Principles and Practice of Medicine. New York: D. Appleton and Company; 1892. p. 184-255.

69. Florey, H. General Pathology based on Lectures delivered at the Sir William Dunn School of Pathology. Philadelphia and London: University of Oxford: W.B. Saunders; 1958. Tuberculosis; p. 829-870.

70. Ridley DS, Ridley MJ. Rationale for the histological spectrum of tuberculosis. A basis for classification. Pathology 1987;19:186-192. [PubMed: 3453999]

71. Cardona PJ, Llatjos R, Gordillo S, Diaz J, Ojanguren I, Ariza A, Ausina V. Evolution of granulomas in lungs of mice infected aerogenically with Mycobacterium tuberculosis. Scand J Immunol 2000;52:156-163. [PubMed: 10931383]

72. Hernandez-Pando R, Pavon L, Arriaga K, Orozco H, Madrid-Marina V, Rook G. Pathogenesis of tuberculosis in mice exposed to low and high doses of an environmental mycobacterial saprophyte before infection. Infect Immun 1997;65:3317-3327. [PubMed: 9234793]

73. Kondo E, Kanai K. Further studies on the increase in cholesterol ester content of the lungs of tuberculous mice. Jpn J Med Sci Biol 1974;27:59-65. [PubMed: 4600529]

74. Kondo E, Kanai K. Accumulation of cholesterol esters in macrophages incubated with mycobacteria in vitro. Jpn J Med Sci Biol 1976;29:123-137. [PubMed: 824482]

75. Korf J, Stoltz A, Verschoor J, De Baetselier P, Grooten J. The Mycobacterium tuberculosis cell wall component mycolic acid elicits pathogen-associated host innate immune responses. Eur J Immunol 2005;35:890-900. [PubMed: 15724242]

76. D’Avila H, Melo RC, Parreira GG, Werneck-Barroso E, Castro-Faria-Neto HC, Bozza PT. Mycobacterium bovis bacillus Calmette-Guerin induces TLR2-mediated formation of lipid bodies: intracellular domains for eicosanoid synthesis in vivo. J Immunol 2006;176:3087-3097. [PubMed: 16493068] 
77. Almeida PE, Silva AR, Maya-Monteiro CM, Torocsik D, D’Avila H, Dezso B, Magalhaes KG, Castro-Faria-Neto HC, Nagy L, Bozza PT. Mycobacterium bovis bacillus Calmette-Guerin infection induces TLR2-dependent peroxisome proliferator-activated receptor gamma expression activation: functions in inflammation, lipid metabolism, and pathogenesis. J Immunol 2009;183:1337-1345. [PubMed: 19561094]

78. Tanigawa K, Suzuki K, Nakamura K, Akama T, Kawashima A, Wu H, Hayashi M, Takahashi S, Ikuyama S, Ito T, Ishii N. Expression of adipose differentiation-related protein (ADRP) and perilipin in macrophages infected with Mycobacterium leprae. FEMS Microbiol Lett 2008;289:72-79. [PubMed: 19054096] . A superb immunohistologic study on lipid bodies in leprosy.

79. Tailleux L, Schwartz O, Herrmann JL, Pivert E, Jackson M, Amara A, Legres L, Dreher D, Nicod LP, Gluckman JC, et al. DC-SIGN is the major Mycobacterium tuberculosis receptor on human dendritic cells. J Exp Med 2003;197:121-127. [PubMed: 12515819]

80. Barreiro LB, Quach H, Krahenbuhl J, Khaliq S, Mohyuddin A, Mehdi SQ, Gicquel B, Neyrolles O, Quintana-Murci L. DC-SIGN interacts with Mycobacterium leprae but sequence variation in this lectin is not associated with leprosy in the Pakistani population. Hum Immunol 2006;67:102-107. [PubMed: 16698431]

81. Jullien D, Sieling PA, Uyemura K, Mar ND, Rea TH, Modlin RL. IL-15, an immunomodulator of T cell responses in intracellular infection. J Immunol 1997;158:800-806. [PubMed: 8992997]

82. Santos AR, Suffys PN, Vanderborght PR, Moraes MO, Vieira LM, Cabello PH, Bakker AM, Matos HJ, Huizinga TW, Ottenhoff TH, et al. Role of tumor necrosis factor-alpha and interleukin-10 promoter gene polymorphisms in leprosy. J Infect Dis 2002;186:1687-1691. [PubMed: 12447749]

83. Pereira AC, Brito-de-Souza VN, Cardoso CC, as-Baptista IM, Parelli FP, Venturini J, Villani-Moreno FR, Pacheco AG, Moraes MO. Genetic, epidemiological and biological analysis of interleukin-10 promoter single-nucleotide polymorphisms suggests a definitive role for $-819 \mathrm{C} / \mathrm{T}$ in leprosy susceptibility. Genes Immun 2009;10:174-180. [PubMed: 19110537]. This is a through genetic and immunologic analysis of the IL-10 SNP in leprosy.

84. Malhotra D, Darvishi K, Sood S, Sharma S, Grover C, Relhan V, Reddy BS, Bamezai RN. IL-10 promoter single nucleotide polymorphisms are significantly associated with resistance to leprosy. Hum Genet 2005;118:295-300. [PubMed: 16163478]

85. Moraes MO, Pacheco AG, Schonkeren JJ, Vanderborght PR, Nery JA, Santos AR, Moraes ME, Moraes JR, Ottenhoff TH, Sampaio EP, et al. Interleukin-10 promoter single-nucleotide polymorphisms as markers for disease susceptibility and disease severity in leprosy. Genes Immun 2004;5:592-595. [PubMed: 15306847]

86. Franceschi DS, Mazini PS, Rudnick CC, Sell AM, Tsuneto LT, Ribas ML, Peixoto PR, Visentainer JE. Influence of TNF and IL10 gene polymorphisms in the immunopathogenesis of leprosy in the south of Brazil. Int J Infect Dis 2009;13:493-498. [PubMed: 19058987]

87. Martin-Fontecha A, Sebastiani S, Hopken UE, Uguccioni M, Lipp M, Lanzavecchia A, Sallusto F. Regulation of dendritic cell migration to the draining lymph node: impact on T lymphocyte traffic and priming. J Exp Med 2003;198:615-621. [PubMed: 12925677]

88. Banchereau J, Steinman RM. Dendritic cells and the control of immunity. Nature 1998;392:245-252. [PubMed: 9521319]

89. Sieling PA, Jullien D, Dahlem M, Tedder TF, Rea TH, Modlin RL, Porcelli SA. CD1 expression by dendritic cells in human leprosy lesions: correlation with effective host immunity. J Immunol 1999;162:1851-1858. [PubMed: 9973451]

90. Simoes, Quaresma JA.; de Oliveira, MF.; Ribeiro, Guimaraes AC.; de Brito, EB.; de Brito, RB.; Pagliari, C.; de Brito, AC.; Xavier, MB.; Seixas Duarte, MI. CD1a and factor XIIIa immunohistochemistry in leprosy: a possible role of dendritic cells in the pathogenesis of Mycobacterium leprae infection. Am J Dermatopathol 2009;31:527-531. [PubMed: 19590423]

91. Miranda A, Amadeu TP, Schueler G, Alvarenga FB, Duppre N, Ferreira H, Nery JA, Sarno EN. Increased Langerhans cell accumulation after mycobacterial stimuli. Histopathology 2007;51:649656. [PubMed: 17927586]

92. Lee DJ, Sieling PA, Ochoa MT, Krutzik SR, Guo B, Hernandez M, Rea TH, Cheng G, Colonna M, Modlin RL. LILRA2 activation inhibits dendritic cell differentiation and antigen presentation to T cells. J Immunol 2007;179:8128-8136. [PubMed: 18056355] 
93. Santos DO, Castro HC, Bourguignon SC, Bastos OM, Rodrigues CR, Van HH, Nery JA, Miranda A. Expression of B7-1 costimulatory molecules in patients with multibacillary leprosy and reactional states. Clin Exp Dermatol 2007;32:75-80. [PubMed: 17305909]

94. Murray RA, Siddiqui MR, Mendillo M, Krahenbuhl J, Kaplan G. Mycobacterium leprae inhibits dendritic cell activation and maturation. J Immunol 2007;178:338-344. [PubMed: 17182571] . An important study of DC function in leprosy. 